Volume 3 Nomor 2, Agustus 2018, halaman 141-150

\title{
KELANCARAN PROSEDURAL MATEMATIS DALAM PEMECAHAN MASALAH KONTEKS PEMASARAN
}

\section{PROCEDURAL FLUENCY IN MATHEMATICAL PROBLEM-SOLVING OF MARKETING CONTEXTS}

\author{
Ai Tusi Fatimah, Nur Eva Zakiah \\ Universitas Galuh, J1. R.E Martadinata No. 150 Ciamis, 46274, Jawa Barat, Indonesia, \\ tusi.fatimah@gmail.com,nureva.math@gmail.com
}

\begin{abstract}
ABSTRAK
Tujuan penelitian ini untuk mengetahui kemampuan kelancaran prosedural matematis siswa dalam proses pemecahan masalah matematika pada konteks pemasaran. Penelitian ini menggunakan pendekatan kualitatif dengan desain deskriptif. Partisipan berjumlah 6orang yang merupakan siswa kelas XII pada salah satu SMK Bidang Keahlian Bisnis dan Manajemen di Kabupaten Ciamis. Instrumen penelitian ini adalah tes tulis dalam bentuk masalah matematika terapan pada konteks pemasaran. Analisis data mengacu pada indikator kemampuan kelancaran prosedural yaitupengetahuan tentang prosedur, pengetahuan tentang kapan dan bagaimana menggunakan prosedur dengan tepat, dan keterampilan dalam melakukan prosedur secara fleksibel, akurat dan efisien. Siswa yang sukses dalam memecahkan masalah matematis konteks pemasaran adalah siswa yang memahami masalah melalui penalaran, mengetahui prosedur yang tepat, menerapkan prosedur secara tepat, fleksibel dan akurat, serta memverifikasi jawaban sehingga masuk akal.
\end{abstract}

Kata Kunci: Kelancaran Prosedural, Pemecahan Masalah, Pemasaran

\section{ABSTRACT}

This research is aimed to determine of student mathematical procedural fluently ability in the process of mathematical problem-solving in the context of marketing. This research is a qualitative approach with a descriptive design. The participants of the research are 6 people of grade XII in one of the Vocational School of Business and Management Expertise in Ciamis Regency. Research instruments is a written test applied mathematical problems in the context of marketing. The data analysis refers to indicators of procedural fluent ability are knowledge of procedures, knowledge of when and how to use procedures appropriately, and skills in performing procedures in a flexible, accurate and efficient. Students who succeed in mathematical problem-solving in the context of marketing are students who understand problems through reasoning, know the right procedures, apply procedures appropriately, flexibly and accurately, and verify the answer so that it makes sense.

Keywords: Procedural Fluency, Problem-Solving, Marketing

How to Cite: Fatimah, A. T., \& Zakiah, N. E. (2018). Kelancaran Prosedural Matematis dalam Pemecahan Masalah Konteks Pemasaran. Mathline: Jurnal Matematika dan Pendidikan Matematika, Vol.3, No.2, 141-150. 


\section{PENDAHULUAN}

Pemecahan masalah matematis menjadi bagian terpenting dalam proses pembelajaran di semua jenjang pendidikan, mulai dari SD sampai perguruan tinggi. Telah banyak penelitian mengenai pemecahan masalah yang dikaitkan dengan faktor-faktor yang mempengaruhi kemampuan pemecahan masalah. Misalnya penelitian yang dilakukan oleh Kuzle (2017) mengenai pemecahan masalah matematis di tingkat sekolah dasar yang dipengaruhi oleh metakognitif. Metakognitif dinyatakan sebagai penggerak dalam proses pemecahan masalah. Husna, et. al. (2013) melakukan tindakan pembelajaran dengan model kooperatif tipe NHT untuk meningkatkan kemampuan pemecahan masalah dan komunikasi matematis siswa sekolah menengah pertama. Pada jenjang perguruan tinggi, pemecahan masalah dalam topik anuitas dan asuransi menunjukkan bahwa mahasiswa masih kesulitan memodelkan suatu masalah dalam bentuk kalimat menjadi model matematika sekalipun masalah rutin (Fatimah, 2016).

Masalah matematis dan pemecahan masalah ditafsirkan berbeda di setiap Negara (Xenofontos \& Andrews, 2014). Perbedaankulturdan cara pandang terhadap suatu masalah menjadi penyebab perbedaan tersebut.Masalah matematis akanmenjadi masalah atau bukan bergantung kepada individu. Yeo (2017) menyatakan bahwa sebuah situasi akan menjadi masalah bagi seorang individu jika terdapat hambatan untuk mencapai tujuan karena pengetahuan, respons, dan perilaku yang dimiliki individu tersebut tidak cukup untuk menghilangkan hambatan tersebut.Sebuah situasi matematis yang sering muncul atau rutin seringkali tidak disebut masalah bagi sebagian individu, menurutnya baru dikatakan masalah jika situasinya baru (masalah non-rutin).

Menurut Blum \& Niss (Xenofontos \& Andrews, 2014), bentuk masalah matematis biasanya ditemukan pada masalah yang murni matematis dan masalah yang diterapkan pada suatu kontek. Masalah terapan adalah masalah matematis yang disajikan dalam konteksmasalah kehidupan sehari-hari atau bidang ilmu lain. Pada masalah terapan, matematika memiliki posisi sebagai alat bantu pemecahan masalah. Salah satu bidang yang menggunakan matematika untuk memecahkan masalah adalah bidang keahlian kejuruan.

Di Indonesia, secara formal, terdapat sekolah menengah kejuruan (SMK) yang merupakan salah satu jenjang sekolah menengah yang mempersiapkan siswanya untuk bekerja sesuai dengan bidang keahliannya. SMK di Indonesia memiliki sembilan bidang keahlian dengan beragam program keahlian. Salah satunya Program Keahlian Bisnis dan Pemasaran dengan kompetensi keahlian bisnis daring dan pemasaran. 
Suatu konsep matematika akan menjadi bermakna jika diterapkan pada suatu konteks. Masalah matematika terapan mengoneksikan matematika dengan suatu konteks bidang kejuruan.Matematika yang digunakan dalam suatu pekerjaan dan dipelajari disekolah kejuruan disebut matematika vokasi (kejuruan) (Bakker, 2014). Pada kompetensi keahlian bisnis daring dan pemasaran banyak menggunakan konsep matematika untuk mengonstruksi konsepnya.Misalnya konsep permintaan dan penawaran menggunakan konsep fungsi linear untuk mengonstruksi fungsi permintaan dan penawaran (Fatimah, et. al., 2018). Hal tersebut menunjukkan betapa pentingnya matematika dalam bidang kejuruan.

Suatu masalah dalam bidang keahlian kejuruan memanfaatkan matematika sebagai alat pemecahan masalah. Seperti yang diungkapkan Schoenfeld, bahwa proses pemecahan masalah melalui beberapa tahapan yaitu membaca tugas, menganalisis, eksplorasi, merencanakan, menerapkan, verifikasi (Olsson, 2018). Dalam masalah matematika terapan kejuruan, proses analisis dan eksplorasi memanfaatkan model matematika untuk merepresentasikan suatu masalah ke dalam bentuk persamaan atau fungsi. Proses perencanaan merupakan penentu suatu prosedur yang akan digunakan sehingga diperoleh solusi.

Pemilihan prosesur yang tepat serta penerapannya dengan benar merupakan salah satu dari bentuk kemahiran matematis.Kemahiran matematika memiliki lima standar, yaitu: pemahaman konsep, kelancaran prosedur, kompetensi strategi, penalaran adaptif, dan disposisi produktif (Kilpatrick, et. al., 2001). Kelancaran prosedur matematis adalah salah satu kemahiran yang harus dimiliki siswa di SMK untuk memecahkan masalahmasalah yang berhubungan dengan keahliannya. Kelancaran prosedur matematik adalah keterampilan dalam menjalankan prosedur secara fleksibel, efisien dan tepat dengan indikator: (1) pengetahuan tentang prosedur; (2) pengetahuan tentang kapan dan bagaimana menggunakan prosedur dengan tepat;(3) keterampilan dalam melakukan prosedur secara fleksibel, akurat dan efisien (Kilpatrick, et. al., 2001).

Prioritas pendidikan matematika di negara-negara barat adalah menemukan cara untuk mendukung pembelajaran bermakna tentang prosedur matematika dan pengembangan keterampilan matematika (Foster, 2015). Namun demikian, siswa seringkali memecahkan masalah matematis dengan penerapan langsung fakta, peraturan, formula, dan prosedur yang ditunjukkan oleh guru, bukan berdasarkan konsep dasar yang dimilikinya (Muis, et. al., 2011). Harapannya, siswa menggunaan strategi dan representasi 
yang fleksibel dan adaptif untuk memecahkan masalah dengan cepat dan akurat (Heinze, et. al., 2009).

Pentingnya kelancaran prosedural dalam memecahkan masalah matematis mendorong peneliti untuk melakukan analisis terhadap kemampuan kelancaran prosedural matematis siswa SMK yang memiliki kompetensi keahlian bisnis daring dan pemasaran dalam proses pemecahan masalah matematis konteks pemasaran.

\section{METODE PENELITIAN}

Metode penelitian yang digunakan dalam penelitian ini adalah kualitatif dengan desain deskriptif. Subjek penelitian sebanyak enam orang yang merupakan siswa kelas XII Sekolah Menengah Kejuruan Swasta Kompetensi Bisnis Daring dan Pemasaran di Ciamis. Subjek penelitian terdiri dari enam orang (S1, S2, S3, S4.S5, dan S6). Untuk mengetahui gambaran kemampuan kelancaran prosedural matematis dalam pemecahan masalah, subjek diberi tes dengan dua masalah matematis dalam konteks pemasaran. Selanjutnya, dilakukan analisis mendalam terhadap hasil tes untuk mengetahui kemampuan kelancaran prosedural matematis. Analisis dilakukan berdasarkan indikator kelancaran prosedural yang dikemukakan oleh Kilpatrick, et. al. (2001) yaitu pengetahuan tentang prosedur, pengetahuan tentang kapan dan bagaimana menggunakan prosedur dengan tepat, dan keterampilan dalam melakukan prosedur secara fleksibel, akurat dan efisien.Masalah matematis dalam konteks pemasaran yang diujikan dalam penelitian ini adalah sebagai berikut.

M1 : Seorang pengusaha memiliki target penjualan dengan rata-rata mingguan lebih dari atau sama dengan Rp.10.000.000,-. Penjualan selama enam hari berturut-turut disajikan dalam tabel berikut.Tentukan besar penjualan hari ke tujuh agar target tercapai.

\begin{tabular}{ccccccc}
\hline Hari ke- & $\mathbf{1}$ & $\mathbf{2}$ & $\mathbf{3}$ & $\mathbf{4}$ & $\mathbf{5}$ & $\mathbf{6}$ \\
\hline $\begin{array}{c}\text { Penjualan } \\
(\mathrm{Rp})\end{array}$ & 9.500 .000 & 11.000 .000 & 9.000 .000 & 8.000 .000 & 12.000 .000 & 12.500 .000 \\
\hline
\end{tabular}

M2 : Permintaan Pasar terhadap Barang $X$ pada Berbagai Tingkat Harga

\begin{tabular}{cc}
\hline Harga Barang $(\boldsymbol{P})$ & Banyaknya Permintaan $(\boldsymbol{Q})$ \\
\hline 50000 & 100 \\
40000 & 200 \\
30000 & 300 \\
20000 & 400 \\
10000 & 500 \\
\hline
\end{tabular}


a. Gambarkan grafik dari data tabel di atas.

b. Tentukan fungsi permintaanya.

\section{HASIL DAN PEMBAHASAN}

\section{Masalah Matematis dalam Konteks Pemasaran}

Masalah-masalah yang disajikan dalam penelitian ini berbentuk word problemdalam konteks pemasaran. Masalah dirancang dengan mengoneksikan konsep matematika dengan bidang kejuruan. Konsep rataan dikoneksikan dengan target penjualan pada masalah M1 dan konsep fungsi dikoneksikan dengan permintaan/ penawaran pada masalah M2. Rancangan soal M1 dan M2 dapat dikatakan sebagai masalah bagi siswa karena soal matematika disajikan dalam situasi baru yaitu dalam konteks pemasaran.Meskipun situasi tersebut mungkin tidak asing lagi bagi siswa, karena konsep penjualan, permintaan, dan penawaran pernah dipelajari pada mata pelajaran-mata pelajaran bisnis daring dan pemasaran. Berdasarkan wawancara terhadap siswa yang menjadi partisipan, kedua soal tersebut belum pernah mereka peroleh sebelumnya.

Masalah M1 dan M2 dapat dipecahkan dengan menggunakan prosedur yang diberikan oleh guru maupun prosedur yang diciptakan melalui penalaran kreatif yang didasari oleh kompetensi yang dimiliki oleh siswa.Masalah matematis M1 merupakan masalah dengan jawaban terbuka dan dapat dipecahkan melalui beragam prosedur di antaranya prosedur rataan. Masalah matematis M2 bagian (a) dapat dipecahkan dengan prosedur membuat grafik koordinat cartesius, sedangkan prosedur pemecahan masalah bagian (b) memiliki beragam prosedursepertimenentukan persamaan garis lurus.Masalahmasalah tersebut berbentuk word problem sehingga memungkinkan siswa untuk memahami kalimat-kalimatnya terlebih dahulu sebelum menentukan prosedur yang tepat.Tahap membaca,menganalisis, mengeksplorasi, dan merencanakan dalam tahapan pemecahan masalah sangat menentukan dalam pemilihan prosedur yang tepat.Tahapan lanjutan pemecahan masalah merupakan penerapan prosedur yang telah ditetapkan. Siswa yang akan berhasil memecahkan masalah adalah siswa yang mengetahui kapan dan bagaimana menggunakan prosedur serta terampil menggunakannya secara fleksibel, akurat, dan efisien.

Koneksi matematis antara pengetahuan matematika dengan pengetahuan keahlian kejuruan selama ini masih jarang dilakukan.Pengetahuan matematika masih kontras dengan pengetahuan di tempat kerja (Nunes, et. al., 1993). Oleh sebab itu, matematika 
kejuruan harus diupayakan terkoneksi dan menjadi transisi dengan dunia kerja (Bakker, 2014). Tugas guru adalah mengatur situasi didaktik dengan memberikan masalah bidang kejuruan yang sesuai dengan keahliannya. Lithner (2017) menyatakan bahwa jika siswa menyelesaikan masalah yang relevan dengan dirinya makaakan memperoleh pengetahuan yang diinginkannya. Merancang masalah matematika dalam bidang kejuruan membutuhkan kemampuan hybrid (Bakker, 2014), yaitu kemampuan matematika dan kejuruan.

\section{Kemampuan Kelancaran Prosedural dalam Pemecahan Masalah M1}

Siswa memecahkan masalah M1 dengan prosedur yang beragam.S1 mengetahui prosedur rataan serta menggunakannya dengan tepat dan fleksibel.Ia mengetahui kapan dan bagaimana menggunakan prosedur dengan tepat. Hal tersebut terlihat dari jawaban pada Gambar 1.

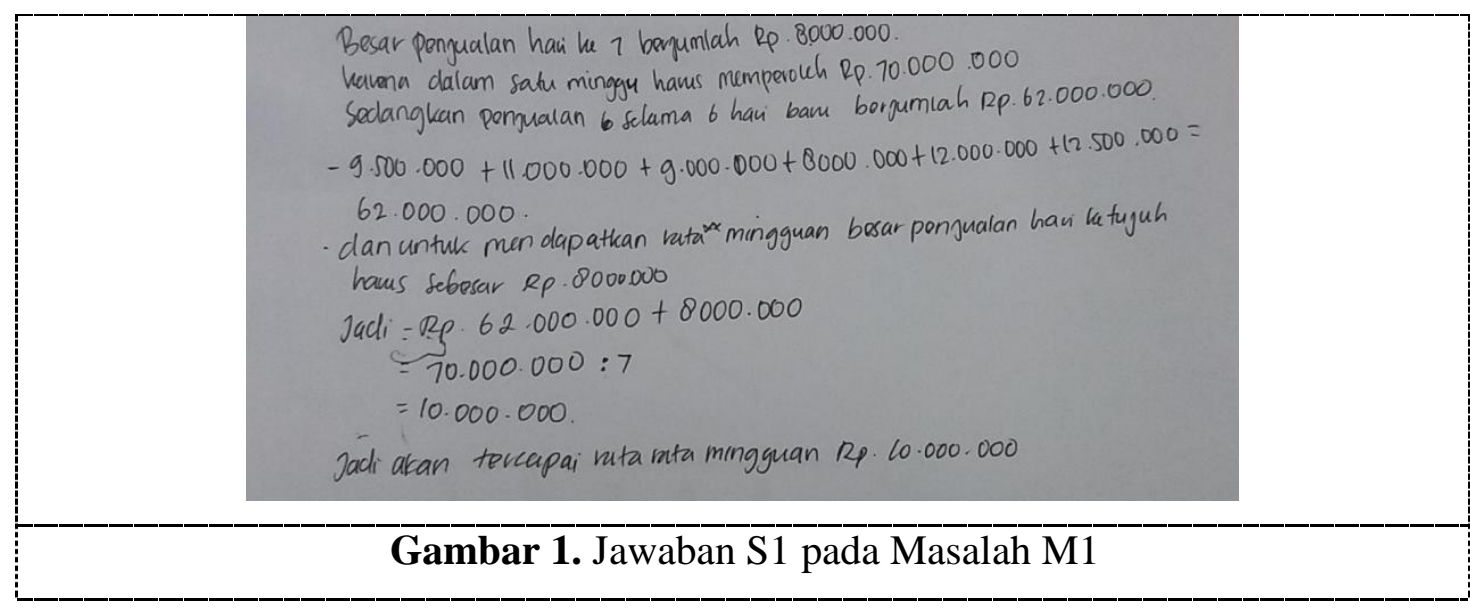

Siswa S2 membuat prosedur sendiri untuk memecahkan masalah M1. Ia membuat barisan bilangan yang sebagian bilangannya berasal dari tabel pada soal. Jawabannya ditunjukkan dalam Gambar 2.

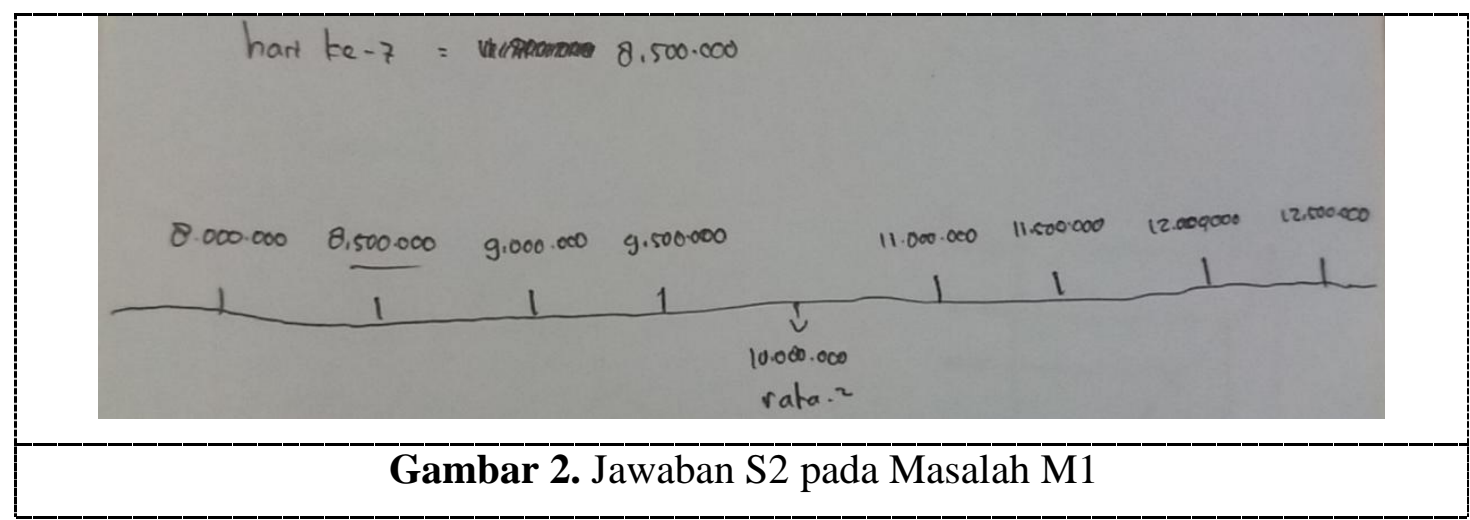

Siswa S3, S4, dan S5 memilih prosedur yang serupa. Mereka menghitung masingmasing kekurangan atau kelebihan dari target harian dan menjumlahkannya. Hasil yang 
diperoleh belum tepat dikarenakan prosedur akhir yang dilakukan tidak tepat. Jawaban S5 ditunjukkan dalam Gambar 3.

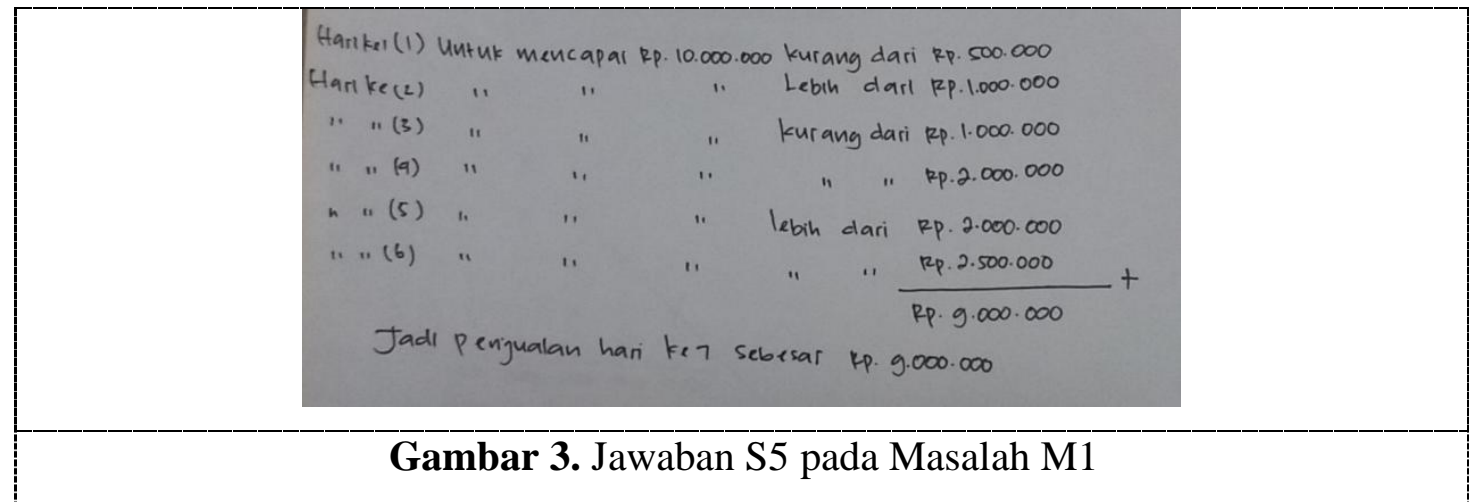

Siswa S6 memilih prosedur rataan, namun penerapannya kurang tepat sehingga hasil yang diperoleh tidak tepat. Jawaban S6 ditunjukkan dalam Gambar 4.

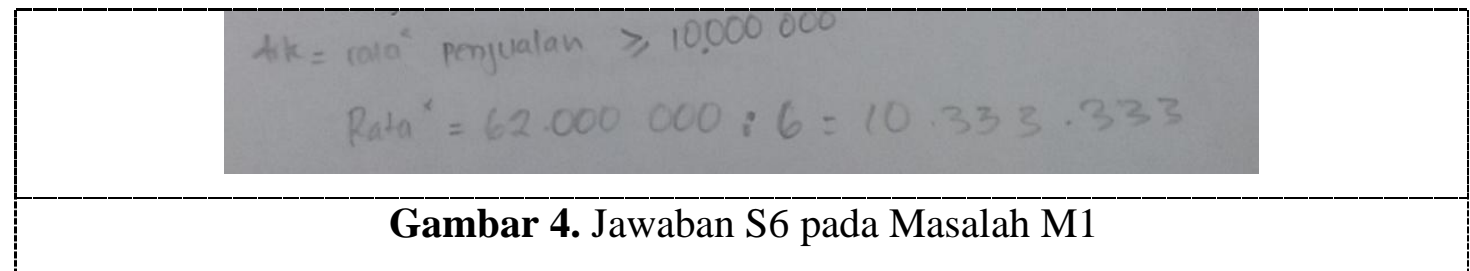

Kelancaran prosedur terkait dengan pemahaman konseptual (Kilpatrick, et. al., 2001).

Selain itu, pemilihan prosedur yang tepat dipengaruhi oleh kemampuan pemahaman dan penalaran matematis (Fatimah, 2016). Siswa yang sukses memecahkan masalah matematis dalam masalah ini adalah siswa yang memahami konsep, menggunakan penalaran, mengetahui prosedur, menerapkannya secara efisien, fleksibel dan akurat, serta memverifikasinya sehingga jawabannya tepat dan masuk akal. Dalam masalah M1, disebutkan rata-rata target penjualan mingguan lebih dari atau sama dengan Rp. 10.000.000,-. Semua siswa memahami dan memprediksi jawaban masalah ini dalam jawaban tunggal.Tidak ada satupun siswa yang menyebutkan (pada jawaban) dengan kalimat "Besar penjualan hari ke-7 minimal Rp..." atau kalimat/simbol lain yang memiliki makna serupa. Hal tersebut terkait dengan pemahaman dan penalaran siswa pada tahapan membaca dan verifikasi masalah word problem.

\section{Kemampuan Kelancaran Prosedural dalam Pemecahan Masalah M2}

Pemecahan masalah matematis siswa pada masalah M2(a) relatif seragam.Para siswa dapat memilih prosedur pemecahan yang tepat yaitu prosedur membuat grafik pada bidang cartesius. S1, S3, S4, S5, dan S6 memilih P sebagai sumbu horizontal dan Q sebagai sumbu vertikal, sebaliknya S2 memilih Q sebagai sumbu horizontal dan P sebagai sumbu vertikal. Penamaansumbu cartesius dengan $\mathrm{P}$ dan $\mathrm{Q}$ menunjukkan bahwa siswa dapat menerapkan prosedur dengan fleksibel melalui pemahaman matematis yang telah 
diperolehnya.Kilpatrick, et. al. (2001) menyatakan bahwa siswa yang memiliki pemahaman matematis dapat memodifikasi atau menyesuaikan prosedur sehingga lebih mudah digunakan. Sebagai contoh, Gambar 5 dan 6 masing-masing merupakan jawaban dari S4 dan S2.

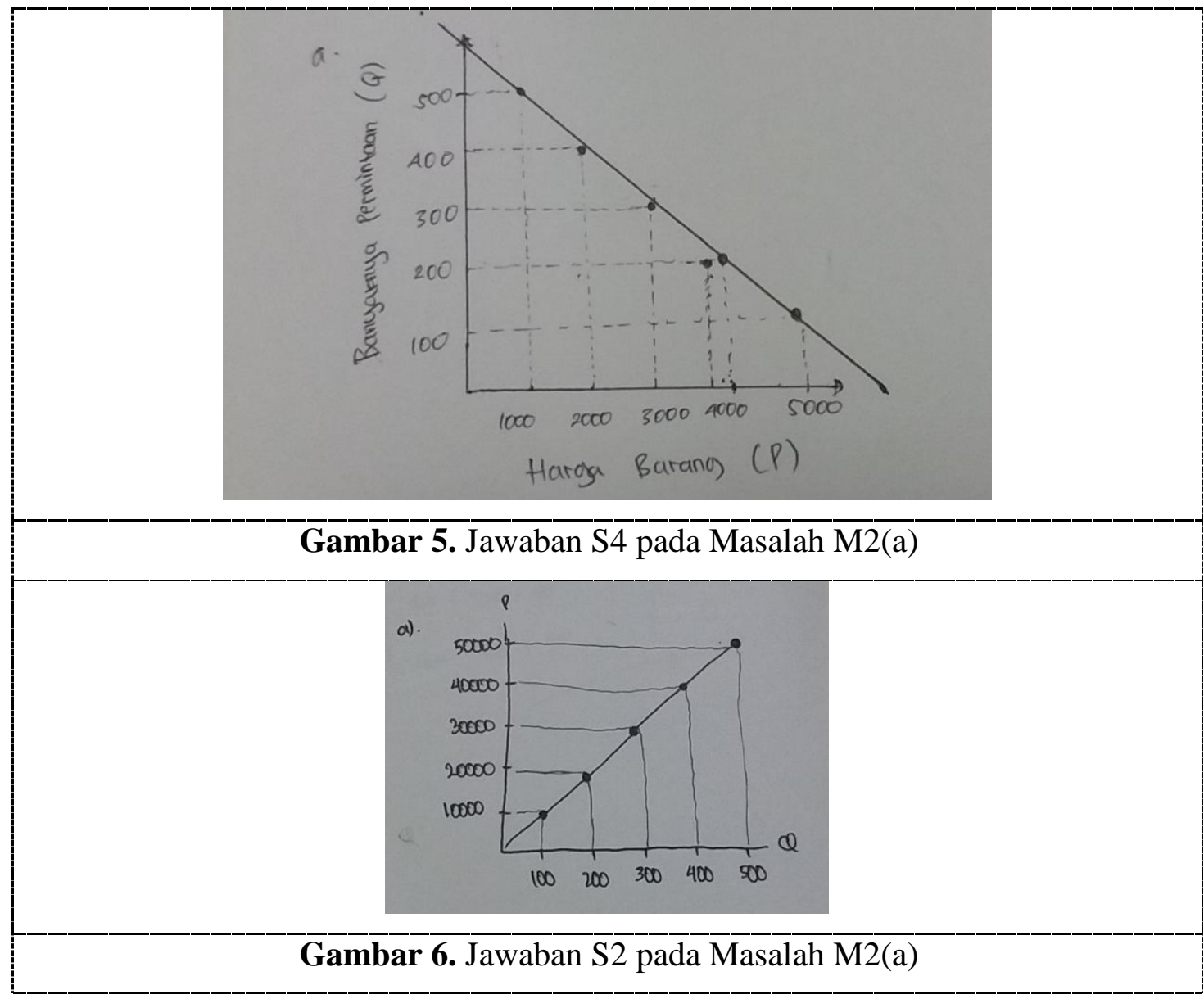

Tanpa kelancaran prosedural yang cukup, siswa mengalami kesulitan mendalami pemahaman mereka tentang ide-ide matematika atau memecahkan masalah matematika (Sari, dkk.,2018). Hal ini seperti pada masalah M2(b), semua siswa menjawab masalah tersebutberdasarkan pengetahuan kejuruannya dan grafik yang diperoleh dalam masalah M2(a). Jawaban tersebut bukan merupakan jawaban yang diharapkan oleh peneliti. Harapannya siswa akan menjawab soal dengan suatu fungsi matematis dengan melakukan prosedur menentukan rumus fungsi linear atau prosedur menentukan persamaan linear dua variabel (garis lurus). Peneliti melihat bahwa jawaban siswa dipengaruhi kuat oleh pengetahuan kejuruan yang dimilikinya.Namun demikian, jawaban siswa M2(b) menunjukkan bahwa terjadi kesesuaian antara grafik yang diperoleh dengan fungsi permintaan yang telah mereka peroleh dalam mata pelajaran keahliannya. Selain itu, pernyataan dalam jawaban M2(b) memverifikasi kebenaran proses pemecahan masalah yang telah dilakukan pada M2(b). Berikut ini jawaban siswa S2 pada masalah M2 (b). 


b). fungsi permintaonnya:
Jjka harga barang lebíh tinggi Maka banuak permintaan
semawn Rendah.

\section{KESIMPULAN}

Kelancaran prosedural merupakan bagian penting pada proses pemecahan masalah konteks pemasaran dalam penelitian ini. Kelancaran prosedural dalam memecahkan masalah konteks pemasaran terkait dengan pemahaman konseptual dan penalaran matematis.Siswa yang sukses dalam pemecahan masalah matematis konteks pemasaran adalah siswa yang memahami konsep melalui penalaran, mengetahui prosedur yang tepat, menerapkan prosedur secara tepat, fleksibel dan akurat, serta memverifikasi jawaban sehingga masuk akal.Masalah matematis konteks pemasaran merupakan word problem yang mentransisikan kalimat-kalimat dalam konteks pemasaran dengan konsep matematis.Pemecahan masalah dalam tahapan membaca, menganalisis, dan mengeksplorasi merupakan tahap yang penting dalam menentukan pemilihan prosedur pemecahan masalah yang tepat. Penerapan dan menjalankan prosedur secara akurat, efisien dan fleksibel akan menghasilkan solusi yang harus diverifikasi sehingga masuk akal.

Penelitian terkait masalah matematis dan pemecahan masalah matematis pada kompetensi keahlian daring dan pemasaran masih belum banyak dilakukan. Oleh karena itu diperlukan penelitian lanjutan untuk menganalisis masalah matematis dalam kompetensi keahlian tersebut atau kompetensi keahlian lainnya.Hal tersebut merupakan salah satu upaya nyata untuk memberikan manfaat pembelajaran matematika bagi siswa SMK yang dipersiapkan dalam dunia kerja/dunia industri.

\section{UCAPAN TERIMAKASIH}

Terima kasih penulis sampaikan kepada LPPM Universitas Galuh Ciamis yang telah membiayai penelitian ini.

\section{DAFTAR PUSTAKA}

Bakker, A. (2014). Characterising and Developing Vocational Mathematical Knowledge. Educ Stud Math, 86 (2), 151-156.

Fatimah, A. T. (2016). Kemampuan Pemecahan Masalah Mahasiswapada Pokok Bahasan Anuitas dan Asuransi. Jurnal Teori dan Riset Matematika (Teorema), 1(1), 19-26.

Fatimah, A. T., Effendi, A., \& Amam, A. (2018). Koneksi Matematis pada Konsep Ekonomi (Permintaan dan Penawaran). Jurnal Teori dan Riset Matematika (Teorema), 2(2), 107-116. 
Foster, R. (2015). Confidence and Competence with Mathematical Procedures. Educ Stud Math, 91 (2), 271-288.

Heinze, A., Star, J.R., \& Verschaffel, L. (2009). Flexible and Adaptive Use of Strategies and Representations in Mathematics Education. ZDM Mathematics Education, 41(5), 535-540.

Husna, Ikhsan, M., \& Fatimah, S. (2013). Peningkatan Kemampuan Pemecahan Masalah dan Komunikasi Matematis Siswa Sekolah Menengah Pertama melalui Model Pembelajaran Kooperatif Tipe Think-Pair-Share (TPS). Jurnal Peluang, 1(2), 8192.

Kilpatrick, J., Swafford, J., \& Findell, B. (2001). Adding It Up -Helping Children Learn Mathematics. Washington: National Academy Press.

Kuzle. (2017). Assessing Metacognition of Grade 2 and Grade 4 Students Using an Adaptation of Multi-Method Interview Approach During Mathematics ProblemSolving. Math Ed Res J, 30(2), 185-207.

Lithner, J. (2017). Principles for Designing Mathematical Tasks that Enhance Imitative and Creative Reasoning. ZDM Mathematics Education, 49(6), 937-949.

Muis, K.R., Franco, G.M., \& Gierus, B. (2011). Examining Epistemic Beliefs Across Conceptual and Procedural Knowledge in Statistics. ZDM Mathematics Education, 43(4), 507-519.

Nunes, T. A., Schliemann, D., \& Carraher, D. W. (1993). Street Mathematics and School Mathematics. Cambridge: Cambridge University Press.

Olsson, J. (2018). The Contribution of Reasoning to the Utilization of Feedback from Software When Solving Mathematical Problems. IntJ of Sciand Math Educ, 16(4), 715-735.

Sari, N., Yusmin, E., \& Nursangaji, A. (2018). Kelancaran Prosedural Siswa dalam Menyelesaikan Soal Persamaan Kuadrat di Kelas X SMKN 2 Pontianak..Jurnal Pendidikan dan Pembelajaran, 7( 2), 1-9.

Xenofontos, C. \& Andrews, P. (2013). Defining Mathematical Problems and Problem Solving: Prospective Primary Teachers' Beliefs in Cyprus and England. Math Ed Res J, 26(2), 279-299.

Yeo, J.B.W. (2017). Development of a Framework to Characterise the Openness of Mathematical Tasks. IntJ of Sciand Math Educ, 15(1), 175-191. 